\title{
Gobernadores en el período indiano. Mudanza de atribuciones debido a la Real Ordenanza de Intendentes de 1782
}

\author{
Agustín Parise \\ "[...] la ambición es respectiva a la condición y posición en que se \\ encuentran los hombres, y hay alcalde de lugar que no se cree \\ inferior a un Jorge IV".' \\ José de San Martín (1778-1850)
}

\section{Propósito}

Es innegable que dentro de las autoridades del período indiano, la figura del gobernador despierta singular interés. Ya sea por la vigencia de la institución a lo largo de los siglos que siguieron al XVI; o debido al alcance y variación de sus funciones durante el tiempo y las extensiones geográficas, entre estas últimas el Río de la Plata.

Previo desarrollar los acápites que forman el presente opúsculo, vale acompañar algunas breves palabras pronunciadas por el profesor Abelardo Levaggi, en los claustros de la Facultad de Derecho de la Universidad de Buenos Aires, cuando sostuvo que el gobernador durante el período indiano nunca faltó, y a diferencia de otras figuras logró ingresar en el período patrio, aun cuando se alteraran algunas de sus competencias ${ }^{2}$.

Esto último se relaciona perfectamente con lo que hemos sostenido $a b$ initio, id est que la vigencia de la figura del gobernador se desplegó desde el siglo XVI hasta la actualidad en la región del Río de la Plata. Sin lugar

1 Enrique Mayochi, El Legado de San Martín, I.S.M., Bs. As., 1978, p. 35.

2 Las palabras acompañadas fueron pronunciadas por el prof. Levaggi, con motivo del seminario sobre "Formación de los poderes nacionales y provinciales", llevado a cabo en el segundo cuatrimestre del año 2002 en los claustros de la Facultad de Derecho de la UBA. 
a dudas esto es sobremanera interesante, y bien vale realizar algunos postulados sobre la mentada evolución.

Siendo conscientes de la necesidad de acotar todo trabajo de investigación a un área determinada, pues consideramos oportuno plantear algunas cuestiones relacionadas con las funciones que debieron llevar a cabo los gobernadores.

Más precisamente en el período inmediato anterior a la entrada en vigencia de la Real Ordenanza para el Establecimiento e Instrucción de Intendentes de Ejército y Provincia en el Virreinato del Río de la Plata del año 1872 (en adelante Ordenanza); y la etapa que le siguió, con los efectos de su aplicación.

Sin la intención de extender demasiado estas palabras previas, pasaremos a desarrollar las funciones que los gobernadores en el Río de la Plata tuvieron, antes y después de la sanción de la ordenanza; como corolario realizaremos algunas reflexiones finales sobre los puntos tratados.

\section{Noción de Gobernador y su innegable importancia}

Como lo hemos manifestado en el apartado anterior, el oficio de gobernador, aun cuando fue variando en sus atribuciones y obligaciones, siempre estuvo presente en la región del Río de la Plata. Existió cuando la zona geográfica era una gobernación, y perduró luego con la creación del Virreinato, en 1776. Quizá no huelgue agregar que este instituto de gobierno ingresó en el período patrio y persiste aún hoy.

Los monarcas peninsulares implantaron en las Indias, sistemas de organización que tenían su fuente inspiradora en sus propias comarcas. Es por ello que se implantó el sistema de gobernadores. El alcance de estos últimos fue variando a lo largo de los siglos, de acuerdo a la región geográfica donde se desempeñaban.

A)Somero catálogo de acepciones

Ante lo pregonado en el apartado anterior, es que no dudamos en realizar un breve catálogo sobre las diversas clases de gobernadores, para luego limitar la visión sobre el que más se relaciona con nuestro planteo inicial.

Cabe previo a esto, indicar que desde el siglo XVI hasta que se implementaron las intendencias a fines el siglo XVIII, se llamaba gober- 
nador a todo el que ejercía la función de gobierno, desde los virreyes hasta los mandatarios de provincias subalternas. ${ }^{3}$ Ante esto se torna imperioso acompañar una breve clasificación, que sin dudas colaborará para comprender la temática. Es significativo que luego de la conquista los gobernadores capitulares desaparecieron y junto a ellos, los resabios feudales que los distinguían. En adelante, los gobernadores fueron solamente funcionarios administrativos. Es dentro de esta clase de gobernadores, donde encontramos el mentado catálogo.

Siguiendo fielmente lo postulado por Ricardo Zorraquín Becú, podemos distinguir nítidamente, por su diversa jerarquía cuatro tipos de gobernadores:

I. Los virreyes: quienes eran gobernadores del distrito en el cual ejercían el mando directo;

II. Los presidentes de las Audiencias Pretoriales: quienes gobernaban la provincia mayor sobre la cual tenía jurisdicción el Tribunal;

III. Los gobernadores y capitanes generales: quienes presidían una provincia menor; y por último

IV. Los gobernadores subordinados: quienes ejercían su imperio en distritos más pequeños, bajo la dependencia de los anteriores.

El punto III es el que nos interesa para el abordaje de este ensayo, ya que el gobernador-intendente (cuestión que desarrollaremos infra) lo reemplazará, al menos aparentemente, en su cargo.

B) Diversas funciones de mando

Enriquece sobremanera tratar de definir, el alcance que tuvieron las funciones de los gobernadores y capitanes generales que presidían provincias menores; toda vez que estos son los que mayor relación tendrán con los gobernadores - intendentes.

Es menester indicar que el gobierno ordinario de cada provincia menor (sin audiencia) fue ejercido, normalmente, por un gobernador nombrado por el rey. Por lo general, fue de capa y espada, para que pudiera acumular la función de guerra. En ese caso, recibió el título adicional de capitán general o comandante general, según fuera su rango. Entre sus facultades estuvo la de designar un teniente general —en el siglo XVIII,

3 Ricardo Zorraquín Becú, La organización política argentina en el período hispánico, Perrot, Buenos Aires, 20 Ed., 1962, p. 143. 
un teniente de rey-, que lo reemplazaba, y tenientes de gobernador en las demás ciudades de su territorio, fuera de la capital. ${ }^{4}$

Los gobernadores ejercieron dentro de sus territorios la máxima autoridad judicial y política. Con frecuencia, estos gobernadores, fueron a la vez capitanes generales, estando así investidos también de la suprema autoridad militar. ${ }^{5}$

No quedaría claro si no se manifestara que los gobernadores ejercían la función de gobierno con gran autonomía, pero los que presidían las provincias menores estaban subordinados jerárquicamente al Virrey, cuyas órdenes debían acatar. Sin embargo, nunca quedó definida con precisión esa dependencia, y en la realidad de los hechos, presidentes y gobernadores actuaron con una gran libertad mientras se mantuvieron en la esfera de sus atribuciones. El Virrey solo intervenía en los asuntos de mucha importancia o de cierta urgencia, pues los demás, o bien eran resueltos directamente por ellos, o bien iban en consulta al Consejo de Indias. Como consecuencia ineludible, los gobernadores mantenían correspondencia directa con las autoridades de la Península y recibían también directamente las órdenes de ellas, sin pasar por la vía jerárquica del Virrey.

Otra característica fundamental del oficio que estudiamos era la unión en la misma persona de las facultades gubernativas, militares y judiciales, con absoluta inhibición en el manejo de la hacienda y en el control de los oficios reales. ${ }^{6}$

Por su parte, la función de gobierno era amplísima y comprendía vastas atribuciones vinculadas con el desarrollo espiritual y material de las poblaciones. ${ }^{7}$

Ya con relación al poder de legislar vale detenernos en el hecho de que, los gobernadores, en el ejercicio de sus atribuciones procedían sancionando ordenanzas generales, ${ }^{8}$ esto último deja entrever un cierto poder legislativo limitado.

4 Abelardo Levaggi, Manual de Historia del Derecho, Depalma, Buenos Aires, 1996, Tomo III, p. 42.

5 José María Ots Capdequí, Manual de Historia del Derecho español en las Indias y del Derecho propiamente indiano, Losada, Buenos Aires, 1945, p. 365.

6 Ricardo Zorraquín Becú, La organización política [...], op. cit., p. 149.

7 Ricardo Zorraquín Becú, Manual de Historia del Derecho argentino, Perrot, Buenos Aires, 1980, Tomo I, p. 131.

8 Ricardo Zorraquín Becú, La Organización Política [...], op. cit., p. 158. 
No estaría completa la referencia al tema, si no se acompaña el hecho de que las ordenanzas (dictadas por los gobernadores), así como las que sancionaban los adelantados, aparentemente requerían aquella confirmación (del Consejo de Indias) pero sin embargo se aplicaban.?

Por cierto que esa autoridad tan amplia y firme dio lugar a abusos que convirtieron a los gobernadores, con alguna frecuencia, en mandatarios deshonestos y arbitrarios. Existían, no obstante, ciertas limitaciones a sus poderes, y otras formas de control político destinadas a evitar el despotismo o a sancionarlo posteriormente. ${ }^{10}$ Desafortunadamente esto excede el campo de actuación de nuestra somera nota; pero su mención era impostergable.

Como corolario podemos afirmar que los gobernadores que presidían provincias menores, estaban autorizados a regir las cuestiones gubernativas, militares, judiciales, y en determinadas oportunidades avanzar sobre las cuestiones legislativas; lo último para poder llevar a buen puerto las primeras.

C) La cuestión en el Río de la Plata

Previo desarrollar los puntos siguientes, presenta interés realizar alguna breve reseña a la cuestión en el Río de la Plata; ya que es dable tener en claro que, previo a la creación del Virreinato del Río de la Plata, en la hoy Buenos Aires, existía autoridad que desempeñaba las funciones de gobernador. Luego con la creación del Virreinato, en la región de referencia, existio la autoridad del Virrey; y por su parte en las diversas gobernaciones que conformaban el cuerpo del territorio rioplatense, existieron gobernadores. Es significativo agregar que durante la segunda mitad del siglo XVIII se establecieron, dentro del distrito, tres nuevas gobernaciones subordinadas, que dependían del mandatario con sede en Buenos Aires ${ }^{11}$ (i.e. Malvinas, Montevideo y Misiones). A esto deben sumarse las que habían existido desde el año 1776, con la creación del Virreinato del Río de la Plata.

9 Ricardo Zorraquín Becú, "El oficio de gobernador en el Derecho indiano», en: Revista de Historia del Derecho, Buenos Aires, 1973, p. 262.

10 Ricardo Zorraquín Becú, La Organización Política[...], op. cit., p. 157.

11 Ricardo Zorraquín Becú, Manual de Historia[...], op. cit., p. 133. 


\section{El establecimiento de Intendencias}

Nos hemos planteado ad initio, tratar sobre las diferencias en el alcance de las funciones de los gobernadores, antes y después de la reforma introducida por el establecimiento, en la América hispana, de las intendencias.

Es teniendo ello presente que no podemos dejar de mencionar, al menos de manera escueta, algunas cuestiones relacionadas con el sistema de intendencias ( $v . g r$ orígenes, recepción y planteos de modificación).

\section{A) Los orígenes en la Península Ibérica}

A semejanza de la mayoría de los institutos que se aplicaron en las Indias, el sistema de intendencias tuvo su origen en el viejo continente. Se perseguía con la instrumentación del sistema de intendencias, una mejora en la economía de las diversas provincias del Reino, toda vez que las fuertes crisis económicas hacían enormes mermas en el erario real. No nos aleja del tema manifestar y repetir, que la corona estaba sufriendo severas dificultades financieras debido a las grandes erogaciones que demandaba la defensa territorial del Reino y colonias.

Si se puede hablar de una causa para el establecimiento de las Intendencias, diríamos sintéticamente que responden al espíritu regalista de la política de los Borbones. ${ }^{12}$

Al parecer el último de los Habsburgos fue quien, ya en 1691, creó el oficio de superintendente en España y nombró a un superintendente en cada una de las veintiún provincias de Castilla, para lo cual cuatro años antes había nombrado un Superintendente General de Hacienda. La guerra, el cambio de dinastía, etc., dejaron en pañales el intento. Hubo que esperar entonces a que Felipe V, en 1711 y 1717 creara la Superintendencia de Ejército y Provincia y luego la Intendencia de Ejército y Marina. ${ }^{13}$

Estas últimas fueron suprimidas en 1721 , y se restablecieron en 1749 , por el rey Fernando VI, ${ }^{14}$ dando comienzo a la corriente intendencista.

12 Ricardo Levene, Lecciones de Historia argentina, Lajouane, Buenos Aires, 1934, Tomo I, p. 216.

13 Jorge Comadrán Ruiz, "La Real Ordenanza de Intendentes de 1782 y las Declaraciones de 1783", en Estudios sobre la Real Ordenanza de Intendentes del Río de la Plata, IIHD, Buenos Aires, 1995, p. 12.

14 Ricardo Levene, Lecciones de Historia [...], op. cit., p. 214. 
B) La acogida en el territorio americano (1764 - 1787)

Dentro del continente americano la creación de las intendencias comienza en algunas regiones, sin método y sin un plan orgánico aparente. Se recuerda que desde mediados de siglo XVIII José del Campillo y Cosío había recomendado extender el sistema de intendencias a las provincias americanas. Pero al procederse al trasplante institucional a tierras del Nuevo Mundo se modifica considerablemente el contenido y orientación de las ordenanzas peninsulares. ${ }^{15}$

Así aparecen sucesivamente la intendencia de ejército y real hacienda de La Habana (31 octubre de 1764), la intendencia de Nueva Orleans (5 julio de 1765), las intendencias de ejército y real hacienda de Caracas (25 noviembre de 1776), etc.

Pero la reforma fundamental, que se estaba gestando desde 1764, iba a consistir en el cambio del sistema de gobierno territorial, implantando un régimen análogo al que regía en España desde mediados del siglo XVIII. ${ }^{16}$ Id est, un proceso de ordenamiento político, administrativo y judicial. ${ }^{17}$ Utilizando las palabras del profesor Abelardo Levaggi podemos asegurar que el objeto fue crear un sistema integrado, sobre la base de un plan racional, lo más semejante posible en todas partes, para promover el crecimiento económico, mejorar la recaudación fiscal, volver más eficiente la administración y reorganizar la defensa. ${ }^{18}$

No estaría completo este reparo si no nos detenemos a señalar, que con la reforma de intendentes el método casuístico empírico de acumulación de oficios fue sustituido por el racionalista de regulación legal de órganos plurifuncionales. La acumulación dejó de ser de oficios, que mantenían su singularidad, para serlo de funciones en un mismo oficio, que resultaba hipertrofiado y sometido a normas generales comunes. ${ }^{19}$

Seguramente emite luz sobre el tema, agregar que la implementación fue lenta y gradual, ya que las autoridades locales de las Indias se encontraban reacias al cambio que les imponían desde la Península.

15 José María Mariluz Urquijo, "La Causa de Hacienda», en: Estudios sobre la Real Ordenanza de Intendentes del Río de la Plata, IIHD, Buenos Aires, 1995, p. 8.

16 Ricardo Zorraquín Becú, "El Oficio de Gobernador [...]”, op. cit., p. 284.

17 Carlos Storni, «La Causa de Guerra», en: Estudios sobre la Real Ordenanza de Intendentes del Río de la Plata, IIHD, Buenos Aires, 1995, p. 129.

18 Abelardo Levaggi, Manual de Historia [...], op. cit., p. 42.

19 Abelardo Levaggi, Manual de Historia [...], op. cit., p. 36. 
Lo manifestado en el párrafo anterior se debía a que no se encontraban lo suficientemente preparados para recibir ciertas novedades que chocaban con los principios difundidos en épocas anteriores. ${ }^{20}$

El sistema de intendencias, por medio de las Ordenanzas de Intendentes, es la fiel expresión del pensamiento ilustrado sobre las respectivas funciones de la Metrópoli y las colonias. No se explicitan esas relaciones, pero su texto se articula muy ajustadamente con el conjunto de disposiciones que se dictan al mismo tiempo para la Península, configurando dos partes bien individualizadas pero integradas en un todo armónico. ${ }^{21}$

Como corolario podemos acompañar lo manifestado por Ricardo Zorraquín Becú, quien aseguró que la reforma intendencial nunca alcanzó a generalizarse en todos los territorios hispánicos. En algunos casos perduraron los gobernadores, aunque disminuidos en su autoridad por la presencia de intendentes de ejército y hacienda. ${ }^{22}$

Habiendo realizado esta breve referencia al paulatino ingreso en el territorio americano, estamos dispuestos a desarrollar la cuestión en el área rioplatense.

C) La Real Ordenanza de Intendentes para el Virreinato del Río de la Plata Fue en el reciente virreinato rioplatense donde Carlos III intentó aplicar el sistema de intendencia a partir del año 1782. Allí se implementó, la Real Ordenanza para el establecimiento e instrucción de Intendentes de Exercito y Provincia en el Virreinato de Buenos Aires, el 28 de enero de 1782; y las Declaraciones del 5 de agosto del año 1783. Estas últimas eran modificatorias de la primera y rigieron las dos en forma armoniosa y uniforme, alterando las Declaraciones a la Ordenanza en las materias sujetas a modificación.

Trataremos infra, las funciones que le acogían al gobernador luego de la implementación de la Ordenanza; y es por ello que, aprovecharemos este apartado, para tratar con mayor profundidad otros temas que excedan a la temática de las funciones de los gobernadores-intendentes, pero que bien vale señalar por el aporte contextual que presentan.

20 Ricardo Zorraquín Becú, "Valoración del Sistema Intendencial», en: Estudios sobre la Real Ordenanza de Intendentes del Río de la Plata, IIHD, Buenos Aires, 1995, p. 217.

21 José María Mariluz Urquijo, «La Causa de Hacienda [...]», op. cit., p. 84.

22 Ricardo Zorraquín Becú, «El Oficio de Gobernador [...]», op. cit., p. 286. 
Entre esos temas conexos es destacable la conformación del virreinato luego de la implementación de la Ordenanza. Esto servirá, ya que facilitará a entender el campo geográfico donde se desempeñaron los gobernadores-intendentes; así como conocer cuantos de estos cargos existían en el Virreinato del Río de la Plata. Podemos resumir que el nuevo sistema dividía el territorio del virreinato en los siguientes distritos: 1. Superintendencia general de ejército y provincia de Buenos Aires; 2. Intendencia de Asunción del Paraguay; 3. Intendencia de Córdoba del Tucumán; 4. Intendencia de Salta del Tucumán; 5. Intendencias de Charcas o Chuquisaca; 6. Intendencia de Potosí; 7. Intendencia de Cochabamba; y 8 . Intendencia de $\mathrm{La} \mathrm{Paz} .{ }^{23}$

Con relación a la Superintendencia General, cabe destacar que la misma fue suprimida en 1788, pues los funcionarios que la desempeñaban, en atención a las atribuciones que les había conferido la Real Instrucción, chocaron con los virreyes. Los dos únicos superintendentes que tuvo el Río de la Plata fueron Manuel Ignacio Fernández y Francisco de Paula Sanz. ${ }^{24}$

Ergo, en la región rioplatense existieron siete gobernadores-intendentes que desempañaron las funciones que esgrimiremos infra.

D) Modificaciones que sufrió la ordenanza

No estaría completa esta breve reseña sin la necesaria mención de las reformas que afectaron a la mentada ordenanza; ya que nos facilitaría conocer qué período de tiempo aproximado contempla la institución sujeta a estudio.

Hemos tenido conocimiento que, por lo menos hasta el año 1821, estuvo en plena vigencia en las Provincias Unidas la antigua y borbónica (ordenanza), con el título de Código de Intendencias. ${ }^{25}$

Sin perjuicio de las Declaraciones de 1783, es menester señalar que el llamado Código de Intendencias, i.e. la Ordenanza y las Declaraciones sufrió —entre 1783 y la fecha de promulgación de la Ordenanza General de Intendentes de 1803 - diversas modificaciones. "Se pueden registrar

23 Ricardo Zorraquín Becú, Manual de Historia [...], p. 136.

24 Ricardo Levene (coord.), Historia de la Provincia de Buenos Aires y formación de sus pueblos, Imp. Oficial, La Plata, 1940, Volumen I, p. 171.

25 Julio César González, La Proyectada Modificación a la Real Ordenanza de Intendentes en el año 1812, Peuser, Buenos Aires, 1942, p. 44. 
por lo menos las siguientes disposiciones que afectaron a la (ordenanza): noventa reales órdenes; veintiocho reales cédulas; dos reales declaraciones y un reglamentom. ${ }^{26}$

Como el lector podrá percibir, hemos demarcado brevemente el contexto formado por el tiempo y espacio. Herramienta que facilitará la comprensión de los temas que desarrollaremos a continuación.

\section{La flamante figura del gobernador - intendente}

La implementación en la América hispana del sistema de intendencias trajo aparejadas innumerables cuestiones que afectaron la estructura que había funcionado durante tres siglos. Entre las alteraciones que se generaron, está la que atañe el centro de este trabajo, id est la tarea que debieron cumplir los gobernadores de provincias menores.

Debido al nuevo régimen, los antiguos gobernadores de los territorios coloniales, fueron sustituidos por los Intendentes gobernadores, sometidos, en parte, a la autoridad del Virrey; y en parte, a la del Intendente general. Puede decirse que el establecimiento en Indias de este régimen de Intendencias, afectó a todo el viejo sistema de nuestra burocracia colonial, desde los virreyes hasta los cabildos municipales. ${ }^{27}$

$\mathrm{Al}$ crearse el cargo de intendente o gobernador-intendente, como se lo denominara a partir de la modificación de $1783 ;{ }^{28}$ los virreyes, como era lógico suponerlo, se resistieron a perder los amplios poderes que habían ejercido durante casi tres centurias, lo que provocó no pocos conflictos de competencias entre aquellos y los nuevos funcionarios. ${ }^{29}$

Como el lector podrá notar, estamos avanzando sobre las polémicas que suscitó la adopción del nuevo sistema, aún cuando no hemos tratado las funciones de los nuevos gobernadores. Esto tiene solo la idea de adelantar, previo el desarrollo de las funciones, que inevitablemente existían los conflictos. Estos trataron de encontrar el marco dentro de la premisa

26 Ricardo Rees Jones, «Las principales modificaciones posteriores a su sanción», en: Estudios sobre la Real Ordenanza de Intendentes del Río de la Plata, IIHD, Buenos Aires, 1995 , p. 158.

27 José María Ots Capdequí, Manual de Historia [...], op. cit., p. 403.

28 María Laura San Martino de Dromi, Intendencias y Provincias en la Historia Argentina, Ciencias de la Administración, Buenos Aires, 1996, p. 46.

29 María Laura San Martino de Dromi, Intendencias y Provincias [...], op. cit., p. 212. 
de que el accionar de los gobernadores-intendentes debía ajustarse a las precisas instrucciones que se les impartían a lo largo del articulado de la (ordenanza) y respetar en todo momento la Recopilación de Leyes de Indias. $^{30}$

Previo pasar a desarrollar cada una de las funciones que tenían las nuevas autoridades de intendencia cabe adelantar que en lo fundamental la reforma consistió en remplazar a los antiguos gobernadores (que ejercían funciones políticas, militares y judiciales), por los nuevos gobernadoresintendentes con poderes de gobierno, hacienda y justicia. En otros términos, los funcionarios que se establecieron en 1783 ya no tuvieron el mando militar, pero en cambio recibieron amplísimas atribuciones de carácter financiero. ${ }^{31}$

Es en este punto, donde consideramos necesario pasar a desarrollar cada una de las diversas funciones que tenía el gobernador-intendente, tratando de acompañar situaciones fácticas que ilustren y enriquezcan la exposición.

A) La función de gobierno o policía

Como hemos podido señalar en el apartado anterior, dentro de las funciones que tuvieron los flamantes gobernadores-intendentes, se encontraba la de gobierno, también llamada de policía. Encontramos diversas remisiones a esta misión, y paso seguido trataremos de exponerlas siguiendo un criterio que facilite su apreciación.

Los funcionarios que centran esta exposición, i.e. los gobernadoresintendentes, tuvieron que desempeñarse entendiendo que ellos eran los responsables del gobierno y de la administración; y que su autoridad no podía ser menoscabada, en el área geográfica donde desempeñaban sus funciones. Su criterio y su actitud, con variantes de tipo personal, quedó fijado para siempre en estas palabras del intendente León y Pizarro, quien, al ver discutida una disposición suya por los alcaldes de Jujuy, dijo que él podía y debía llamar a mi teniente, subdelegados y alcaldes para advertirles su obligación y exhortarles a que cumplan con ella en las causas que juzgasen. $^{32}$

30 María Laura San Martino de Dromi, Intendencias y Provincias [...], op. cit., p. 232. 31 Ricardo Zorraquín Becú, Manual de Historia [...], p. 137.

32 Edeberto O. Acevedo, "La causa de Policía o Gobierno", en: Estudios sobre la Real Ordenanza de Intendentes del Río de la Plata, IIHD, Buenos Aires, 1995, p. 48. 
Teniendo presente que su obligación era la de administrar conforme a la letra de la Ordenanza, podemos asegurar que ésta estableció un verdadero sistema de fomento y trabajo. ${ }^{33}$

Los gobernadores-intendentes atendieron, de preferencia, el orden material de las ciudades de su mando pues en ellas encontraron ancho campo para sus iniciativas ya que era preciso y urgente mejorar, reformar, cambiar, reestructurar, auspiciar, etc.

Gracias a sus inspecciones o visitas, a los informes que obtuvieron, a la colaboración de los cabildos o de simples particulares, fueron conociendo y apreciando sus diferentes regiones, de manera tal que, aunque éstas eran distintas y se hallaban alejadas unas de otras, contenían problemas comunes que era urgente resolver.

Muchas de las medidas tomadas por los intendentes se dieron aprovechando, (como lo hemos manifestado supra), las indicaciones prácticas de la Ordenanza para acudir a la realización de obras públicas de imprescindible necesidad. ${ }^{34}$

Entre las funciones de policía o gobierno que se desprendían de la Ordenanza, podemos señalar que el gobernador-intendente debía informar sobre la calidad de las tierras, las producciones, industria, comercio, ríos que podrían hacerse navegables, acequias que convendría construir, estado y mejora de puentes y caminos; averiguar la vida y costumbres de los vecinos, y corregir a los ociosos; ejercer la policía de los caminos y cuidar la limpieza y ornato de las calles; fomentar la agricultura y la aplicación de los naturales a algunas de sus faenas, ${ }^{35}$ etc.

En la letra del artículo $43^{\circ}$ de la Ordenanza, se mandaba a los gobernadores-intendentes, por medio de ingenieros competentes, la formación de mapas topográficos de sus provincias, señalando y distinguiendo los términos de ellas, sus montañas, bosques, ríos y lagunas.

Persiguiendo un fin ilustrativo, en el Río de la Plata —c. 1790—, en cumplimento del citado artículo, el Virrey Juan José Vértiz tuvo que mendigar en general todas aquellas referidas noticias recomendando a su

33 María Laura San Martino de Dromi, Intendencias y Provincias [...], op. cit., p. 47. 34 Edeberto O. Acevedo, «La causa de Policía o Gobierno», en: Estudios sobre la Real Ordenanza de Intendentes del Río de la Plata, IIHD, Buenos Aires, 1995, p. 56.

35 Ricardo Levene (coord.), Historia de la Provincia[...], op. cit., p. 171. 
sucesor que quedase fijado en la secretaría el mapa geográfico de la América meridional. ${ }^{36}$

Tratamiento particular merece la cuestión de la relación con el Cabildo Municipal. Esto es significativo ya que puede señalarnos el alcance de su autoritas, en la práctica. Considerando esto, cabe sostener que los gobernadores-intendentes tenían cierto imperio sobre los cabildos, que debían darles cuenta de lo que resolvieran para que el intendente lo aprobara. ${ }^{37}$ Como se desprende de lo manifestado supra, la autonomía de los cabildos municipales sufrió rudo golpe con la promulgación de la (Ordenanza). Atribuciones que antes les eran peculiares en orden a las causas de justicia y policía, pasaron ahora a ser privativas de los gobernadoresintendentes si bien los municipios no dejaron de participar en su cumplimiento.

También vieron disminuidas sus atribuciones los cabildos en el orden fiscal, en virtud de las facultades que a este respecto se concedieron a las Juntas Municipales, a los gobernadores-intendentes y a la Junta Superior de Hacienda. ${ }^{38}$ (vide infra punto IV. b)

Del ejemplo expuesto a continuación, se desprenderá que los mentados poderes de los gobernadores-intendentes sobre los cabildos, en oportunidades, se veían limitados o acotados por el contralor del Virrey. Vale recordar que el Gobernador Olaguer Feliú se negó a aprobar la elección hecha el $1^{\circ}$ de enero de 1796 de la persona elegida por el Cabildo, para desempeñar el cargo de Fiel Ejecutor, ordenando, al mismo tiempo, que se procediera a nueva elección. De inmediato el Cabildo resolvió unánimemente declarar bien hecha la elección por ser el electo persona digna, vecino honrado y con las condiciones requeridas por las leyes, y que no podía considerarla nula hasta que el Gobernador explicase los motivos que tenía para invalidarla, debiendo la corporación si lo considerase legítimo, proceder a lo que hubiera lugar.

Contestó el Gobernador al Cabildo, por oficio, en los siguientes términos: "No es a Usía a quien Yo debo dar Cuenta de los motivos que tenga para desaprobar la elección que hizo de d. n. Zacarías Pereira para el Empleo de Rexidor Fiel Executor en el presente año; y residiendo en mí,

36 Antonio Zinny, Historia de los Gobernadores de las Provincias Argentinas desde 1810 hasta la fecha, Imp. Ed. Mayo, Buenos Aires, 1879, Tomo I, p XXXVII.

37 Ricardo Zorraquín Becú, Manual de Historia [...], p. 137.

38 José María Ots Capdequí, Manual de Historia [...], op. cit., p. 404. 
como reside la autoridad, y facultad de aprobar o desaprobar, según tenga por conveniente las Elecciones q.e. Vsi debe hacer para los Empleos Concegiles, Toca a Usía, dar cumplimiento a mi determinación, o hacer el recurso q.e. tuviese por conveniente».

Ante esta contestación el Cabildo de Montevideo acordó dirigir al Virrey una representación para que resolviera, según lo estimase conveniente, el conflicto. Y el Virrey, haciendo plena justicia a la actitud del Cabildo, resolvió confirmar a la persona que este había elegido para el cargo de Fiel Ejecutor. ${ }^{39}$

B). Las cuestiones de hacienda

A diferencia del período anterior a la sanción de la Ordenanza, y en virtud del Art. $2^{\circ}$, se quitó al Virrey el conocimiento de todas las materias de Real Hacienda. ${ }^{40}$ Estas fueron a pasar al gobernador-intendente, toda vez que el asunto tenga conexión con mi Real Hacienda, como dice el Art. $220^{\circ}$ de la (ordenanza). ${ }^{41}$ Lo antedicho fue uno de los cambios más trascendentales que presentó la pieza normativa del año 1782 .

Como lo hemos manifestado en otra oportunidad previa, la causa de hacienda reviste fundamental importancia dentro de la normativa de la (ordenanza). Ello se refleja en el gran número de artículos que aquel texto legal dedica a su tratamiento (ciento setenta y ocho artículos sobre un total de doscientos setenta y seis). ${ }^{42}$ Tener esto presente colaborará para entender de manera acabada los puntos a desarrollar infra.

El punto de funciones de hacienda, debía correr bajo su privativa inspección y conocimiento de la dirección de las rentas reales, ejerciendo la jurisdicción contenciosa que las leyes de Indias concedían a los Oficiales Reales para hacer efectiva la percepción de la renta, con absoluta inhibición de los tribunales y audiencias, a excepción de la Junta Superior de Hacienda. ${ }^{43}$

Produciremos un breve catálogo en el cual esgrimiremos algunas cuestiones que ilustran algunas de las competencias de los gobernadoresintendentes en la materia de hacienda.

39 José Salgado, El Gobierno Indiano, Imp. Siglo Ilustrado, Montevideo, 1918, p.191.

40 María Laura San Martino de Dromi, Intendencias y Provincias [...], op. cit., p. 210.

41 Carlos Storni, «La Causa de Guerra [...]”, op. cit., p. 129.

42 María Laura San Martino de Dromi, Intendencias y Provincias [...], op. cit., p. 47.

43 Ricardo Levene (coord.), Historia de la Provincia [...], op. cit., p. 171. 
Verbi gratia, ellos, asimismo, debían vigilar la percepción de los caudales y su puntual entrega en las cajas, la exactitud de las cobranzas de las rentas y el proceder y comportamiento de los funcionarios subalternos encargados de su recaudación. ${ }^{44}$ Ergo, debían proceder contra los morosos (conf. Art. $\left.106^{\circ}\right) .^{45}$

Colabora a defender esta tesitura el hecho de que don Vicente Escobar, el subdelegado de San Miguel de Tucumán, intervino eficazmente en los asuntos de hacienda, logrando aumentar las recaudaciones del ramo pulperías, desempeñando el empleo de coronel de las milicias urbanas, trabajando en el adiestramiento de ellas; y en efectuar un nuevo empadronamiento de los indios de su jurisdicción, con lo que aumentaron las entradas del ramo de tributos. ${ }^{46}$

Con acierto ha observado el profesor Haring que si con la implantación del sistema de Intendencias se consiguió sanear la administración del Estado español en Indias, incrementándose considerablemente los ingresos del Tesoro, los beneficios que por este lado se alcanzaron quedaron contrarrestados con creces por el error político que implicó desplazar a los criollos de los puestos de gobernadores, alcaldes mayores y corregidores, y sustituirlos por funcionarios peninsulares que absorbieron sus atribuciones políticas y administrativas desde los nutridos cuadros burocráticos de las distintas Intendencias. ${ }^{47}$

\section{C) Las causas de guerra}

La competencia del gobernador-intendente en la causa de guerra está regulada por los arts. $220^{\circ}$ a $275^{\circ}$. En esta materia, él estaba encargado del transporte, armamentos, alimentación, pertrechos, etc. de la tropa, es decir, de todo aquello que tuviere conexión con la Real Hacienda (Art. $\left.221^{\circ}\right),{ }^{48}$ con especial referencia a la subsistencia y curación de la tropa ${ }^{49}$

Lo mencionado en el párrafo supra es consecuencia inmediata de lo que hemos ilustrado en el apartado anterior.

44 María Laura San Martino de Dromi, Intendencias y Provincias [...], op. cit., p. 234. 45 Ibid, p. 277.

46 Edeberto O. Acevedo, "Notas sobre la Justicia en la Intendencia de Salta", en: Revista del Instituto de Historia del Derecho «Ricardo Levene» No 9, Buenos Aires, 1958 , p. 60.

47 José María Ots Capdequí, Manual de Historia [...], op. cit., p. 404.

48 María Laura San Martino de Dromi, Intendencias y Provincias [...], op. cit., p. 48.

49 Carlos Storni, «La causa de Guerra [...]», p. 135. 
Sin embargo, el gobernador-intendente carecía del mando efectivo de la tropa (Art. 221 ${ }^{\circ}$ ) que quedaba en manos del Virrey, a quien él debía obediencia en casos bélicos (Art. 269\%)..$^{50}$ Esto era una manera de limitar las atribuciones amplias de poder que había recibido el gobernador-intendente por medio de la ordenanza.

Se trató de compensar la importante injerencia en temas de hacienda, con una limitación en las cuestiones castrenses. Ya que entre las dos se llevaba delante gran parte del manejo de las colonias.

D) El ámbito de la justicia

Con relación a la administración de justicia que los gobernadoresintendentes podían ejercer, cabe hacer una advertencia previa. Esta es que los recursos podían ser tratados ante la Audiencia de Buenos Aires, desde su creación; y anteriormente ante la Audiencia de Charcas. En las restantes cuestiones, id est, las que cuadraran en primera u ordinaria instancia era competencia del ámbito intendencial.

Al formarse la Audiencia de Buenos Aires, reales provisiones se dirigieron, empleando por primera vez como propio el nombre del soberano, a los gobernadores-intendentes. Ellas tenían por objeto notificar a todos los habitantes del virreinato, la instalación del tribunal, a fin de enterarles de la interposición de sus recursos, cuando se sintiesen agraviados. Prevenía a los gobernadores (intendentes) y justicias ordinarias, les admitiesen en los de apelación para aquella nueva real audiencia, y no para la de Charcas, si así correspondía. Una vez recibidas, (las reales provisiones) por los gobernadores-intendentes, le dieron debido obedecimiento, conforme a derecho; procediendo a su publicación en la más solemne forma. ${ }^{51}$

Ya con relación a las cuestiones ordinarias o de la actualmente llamada primera instancia, los gobernadores-intendentes no obraban por sí solos, sino que se valían de la cooperación de funcionarios capacitados al efecto en quienes delegaban el ejercicio de ciertas funciones judiciales. ${ }^{52}$

Se sabe que ejercían el poder judicial por medio de sus tenientes letrados quienes debían atender por sí la jurisdicción contenciosa, civil y criminal en la capital y su particular territorio. ${ }^{53}$

50 María Laura San Martino de Dromi, Intendencias y Provincias [...], op. cit., p. 48.

51 Enrique Ruíz Guiñazú, La Magistratura Indiana, Fac. Derecho UBA, Buenos Aires, 1916, p. 213.

52 María Laura San Martino de Dromi, Intendencias y Provincias [...], op. cit., p. 232.

53 Edeberto O. Acevedo, "Notas sobre la Justicia [...]”,op. cit., p. 67. 
Quizá no huelgue reiterar que a los gobernadores-intendentes les correspondió velar por la buena administración de justicia, sin tener ellos funciones judiciales, que recayeron en sus tenientes letrados o asesores. ${ }^{54}$

Corolario, podemos sostener que a semejanza del período anterior al dictado de la ordenanza, el gobernador-intendente pudo desempeñar tareas judiciales de contralor, aún cuando el alcance de las mismas haya variado.

E) Breve mención sobre la competencia legislativa

Así como lo hemos hecho con relación a los otros gobernadores cabe acompañar lo relativo a la capacidad de legislar que tenían los gobernadores-intendentes. Esta capacidad, como lo demostraremos con el desarrollo del párrafo infra, fue una cuestión de excepción. En virtud de lo previsto en los arts. $68^{\circ}$ y $69^{\circ}$ de la (ordenanza) el intendente, podía dictar ordenanzas para la creación, mantenimiento y administración de las alhóndigas y pósitos. Así, por ejemplo, invocando el Art. $68^{\circ}$ de aquel ordenamiento legal, el intendente de Cochabamba, Francisco de Viedma, dio una instrucción provisional sobre pósitos. ${ }^{55}$

Lo trascendental era que la norma versara sobre cuestiones que se dirijan a proteger el erario real, ya que en esas oportunidades bien valía dictar algún bando u ordenanza.

\section{Recapitulación y acotaciones}

Todo trabajo de investigación merece algunas palabras finales que le den al marco de cierre. Ante esto es que no dudamos en realizar una somera recapitulación de los temas tratados. En primer término hemos desarrollado las diversas acepciones del vocablo gobernador, deteniéndonos en los que presidían una provincia o región menor. De estos últimos hemos descripto sus funciones previo al dictado de la ordenanza. Pudimos notar los ámbitos en los cuales el gobernador era competente. Seguidamente dedicamos algunas líneas al sistema de intendencias, y su gestación en la Península y posterior penetración en el continente americano.

54 Abelardo Levaggi, Manual de Historia [...], op. cit., p. 42.

55 María Laura San Martino de Dromi, Intendencias y Provincias [...], op. cit, p. 271. 
Innegable es que ello nos guió al análisis de la ordenanza y algunas de sus modificaciones.

Corolario hemos desmenuzado las funciones del gobernador-intendente; las cuales se desprendieron de la mentada ordenanza.

Luego de la breve recapitulación podemos formular algunas conclusiones, que sin lugar a dudas enriquecerán el presente ensayo.

Consideramos que el cambio más notorio entre las funciones de las autoridades estudiadas, luego de la implementación de la ordenanza, se postuló con la delegación de la materia relativa a hacienda en el campo de actuación de los gobernadores-intendentes. Asimismo se nota que se aminoró la injerencia castrense; mientras que el campo judicial se acotó a la mera supervisión y delegación en tenientes letrados.

A lo largo de las líneas que forman esta humilde nota, consideramos haber abierto la puerta para futuras investigaciones, que no duden en ahondar los temas que hemos tratado someramente; toda vez que compartimos las palabras de Juan Goethe, las cuales guiaron nuestro trabajo, quien recela de la idea, no logra tampoco captar nunca el concepto. ${ }^{56}$

56 G. Radbruch, Filosofía del Derecho, Rev. del Derecho Privado, Madrid, 1933, p. 43. 